International Journal of Instruction e-ISSN: 1308-1470 • www.e-iji.net

Article submission code: 20210210050447

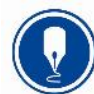

January $2022 \bullet$ Vol.15, No.1

p-ISSN: 1694-609X

pp. 327-346

Received: 10/02/2021

Revision: 26/06/2021
Accepted: 21/07/2021

OnlineFirst: 24/10/2021

\title{
Effects of Brain-Based Teaching Approach Integrated with GeoGebra (B- Geo Module) on Students' Conceptual Understanding
}

\section{Siti Seri Kartini Mohd Yatim}

Universiti Sains Malaysia, Malaysia, serisskmy@gmail.com.my

\section{Salmiza Saleh}

Assoc. Prof., Universiti Sains Malaysia, Malaysia, salmiza@usm.my

\section{Hutkemri Zulnaidi}

Faculty of Education, University Malaya, Malaysia, hutkemri@um.edu.my

Wun Thiam Yew

School of Educational Studies, Universiti Sains Malaysia, Malaysia, tywun@usm.my

Siti Ainor Mohd Yatim

School of Distance Education, Universiti Sains Malaysia, Malaysia, ainor@usm.my

$$
\mid
$$

The Brain-Based Teaching Approach is a strategy that implements methods from a brain-based learning (BBL) model. This approach was designed to be compatible with the inclinations and optimal functions of the individual brain to ensure that students can learn effectively. The module uses the Brain-Based Teaching Approach integrated with GeoGebra Software (B-Geo Module) to help students' conceptual understanding of the topic of differentiation. Therefore, this study aims to explore the possible effects of the Brain-Based Teaching Approach with the integration of GeoGebra Software on conceptual understanding of the topic of differentiation in rural secondary schools in Malaysia. This study used a quasidesign of pre-test and post-test experiments involving 118 form 4 students from rural secondary schools. The researchers used cluster sampling techniques for school selection and intact group for sample selection. The school selection was divided into two groups, namely, the control group using conventional information and communication technology (ICT) modules and the experimental group using the B-Geo Module. The instrument used was the Conceptual Understanding Test of Differentiation. The results of the data analysis show that the conceptual understanding of the topic of differentiation amongst rural secondary school students increased when using the Brain-Based Teaching Approach with the integration of GeoGebra Software.

Keywords: brain-based teaching approach, additional mathematics, differentiation, GeoGebra, conceptual understanding

Citation: Yatim, S. S. K. M., Saleh, S., Zulnaidi, H., Yew, W. T., \&Yatim, S. A. M. (2022). Effects of brain-based teaching approach integrated with GeoGebra (b-geo module) on students' conceptual understanding. International Journal of Instruction, 15(1), 327-346. https://doi.org/10.29333/iji.2022.15119a 


\section{INTRODUCTION}

Additional Mathematics is an elective subject at the high school level in Malaysia. Additional Mathematics is also the most intimidating subject because it is considered the most difficult amongst other subjects (Yahya \& Amir, 2018). By its very nature, this subject encourages meaningful and challenging study. Because students are usually taught about the relevance of Additional Mathematics in school, they frequently believe that the subject is unimportant and that mastering it is not required (Abu \& Leong, 2014). Students who take Additional Mathematics have a good chance of continuing their study in the fields of Science, Technology, Engineering, and Mathematics (STEM). According to a 2015 assessment from the Program for International Student Assessment (PISA), only 13.2 percent of Malaysian students are interested in science and engineering professions (Program for International Student Assessment Report, 2015). The ineffectiveness of teaching strategies and aid materials is amongst the reasons why student' optimum learning and development for Science and Mathematics subjects cannot be generated (Fazil \& Salmiza, 2016; Jumiran, 2014). Students tend to think that learning Mathematics is hard because some topics require abstract knowledge, making understanding the conceptual knowledge of certain topics difficult (Saad, 2002; Yahya \& Amir, 2018). Mathematical teaching and learning (T\&L) focuses on formula memorization and exercises, as well as skills for answering examination questions and teacher-centred teaching practise. This procedure makes students anxious and makes it harder for them to follow the classroom discussions (Abidin, 2012; Puteh \& Khalin, 2016; Yahya \& Amir, 2018).

According to a report obtained by the researchers (Malaysian Board of Examination, 2018), the percentage of students who failed Additional Mathematics in the Malaysian Certificate of Education (or Sijil Pelajaran Malaysia [SPM]) for third year in a row increased from 22.2 percent to 22.7 percent and then to 24.2 percent from 2015 to 2017. In 2017, the average grade for Additional Mathematics (5.81) remained low when compared to other courses. Similarly, the percentage of rural school students who failed the subject in the previous three years rose from 28.18 percent to 28.74 percent, then to 31.35 percent (Examination Board report, 2018). A large percentage gap of passing students still exists between rural and urban students in 2017, that is, $68.65 \%$ and $78.27 \%$, respectively. The government's goal of closing the gap between rural and urban students, as stated in Malaysia's National Education Blueprint 2013-2025, has yet to be achieved. Students' confidence to register Additional Mathematics as a subject for the SPM has also decreased. The number of SPM candidates for Additional Mathematics was 152,004, 126,880 and 125,636 in 2015, 2016 and 2017, respectively (Examination Board, 2018). Students are less motivated to register Additional Mathematics for SPM because obtaining good grades for this subject is difficult.

Differentiation is one of the most challenging topics in Additional Mathematics, as claimed by the students. According to the interviews of Nasir et al. (2013), Additional Mathematics teachers argue that differentiation is the most difficult topic to teach. Kailani and Ismail (2010) showed that students still do not understand the concepts and strategies for dealing with differentiation problems (Arshad \& Abdullah, 2014). 
Differentiation is a crucial issue for students to comprehend in order to grasp the challenging concept of calculus (Orton, 1983; Park, 2013; Thompson, 1994; Zandieh, 2000; Zengin, 2018).

Additional Mathematics teachers and students in the twenty-first century must continue to alter and evolve in response to global trends. Mathematics teachers must be 'literate' with the changing times as a result of innovations in mathematics learning (Nurjanah et al., 2020). T\&L utilising information and communication technology (ICT) is critical in order for students and teachers to become familiar with the most up-to-date technologies for this subject. PISA 2015 was also the first time that it was based on ICT (PISA Report, 2015). The Malaysia Education Blueprint (PPPM) 2013-2025 preliminary report stated that the first wave, which was to bring the government's desire for the seventh PPPM shift, prompted the Ministry of Education to devote the most capital for infrastructure and ICT in classrooms. However, based on the inspection report of the Inspectorate of Schools (JNJK) in 2012 and 2013, the percentage of teachers using technology across Malaysia was very low, at $0.00 \%$ and $1.20 \%$, respectively (Khor \& Ruzlan, 2016). Despite the numerous advantages of employing technology in the classroom to teach Mathematics, previous research has revealed that overall, technology adoption in the classroom is slow (Cuban et al., 2001). The reason is that teachers do not have enough support modules and teaching aid materials involving the use of ICT for the topic of differentiation in helping students' conceptual learning. Based on the researchers' initial study, only $22.2 \%$ of teachers use the teaching module during T\&L of Additional Mathematics in the classroom.

Learning mathematics particularly the complex Additional Mathematics causes a variety of issues. The issue found in the implementation is that understanding the concept of a topic in Additional Mathematics is difficult, making solving problems difficult for students. Additional Mathematics learning is teacher-centred, and students become passive. Thus, active learning methods are necessary for the learning process to support and optimise students' ability in understanding concepts and problem-solving. Based on this issue, the learning process requires learning methods or models that help students become active and fun (Purwadi et al., 2019). Brain-Based Learning (BBL) is learning that makes students active and enjoy learning. BBL is related to how our brain functions naturally in the learning process (Jesen, 1995). This model focuses on how to optimise brain capacity. Students will enjoy learning when they are ready to learn. The role of the teacher is important to create good conditions for learning. Teachers should prepare students and bring them into learning when they are bored. Studies showed that BBL is positive in improving mathematical achievement (Kartikaningtyas et al., 2017).

Based on the issues and discussions mentioned above, the researchers determined that a study is required to assist the teachers in developing a Brain-Based Teaching Approach integrated with GeoGebra for Additional Mathematics, particularly for the topic of differentiation to help improve students' conceptual learning. ICT modules have been successfully designed based on earlier studies, as evidenced by Hutkemri (2013), Ayu Erlina (2013), and Nordin et al (2010). These ICT modules have addressed the 
challenges with conceptual, procedural, and problem-solving difficulties that students have when learning Mathematics.

\section{Literature Review}

\section{Brain-Based Teaching Approach}

The Brain-Based Teaching Approach (BBTA) is a strategy implemented based on the 12 Principles of BBL developed by Caine and Caine $(1991,2003)$ through three teaching techniques. The three elements of teaching (Caine \& Caine, 1991; 2003) associated with BBL are (i) Calm and Sensitive (emotional climate) - creating a full learning environment by flooding students with many educational experiences; (ii) Integration of various enriched experiences (teaching) - eliminating fear amongst students whilst maintaining a very challenging environment; (iii) Active Processing (reinforcement) - allowing students to actively integrate and access information to process it.

The Brain-Based Teaching Approach is believed to improve learning because of its holistic approach to students. This learning approach conforms to the best operating principles of the brain's natural processes, aiming to achieve attention, understanding, meaning and memory (Jesen, 1995). Learning that is 'authentic,' in the sense that it is related to real-world challenges and applications, can help students learn more effectively (Caine \& Caine, 1991, 2005; Jesen, 1995; Sousa, 1995). Considering that the development and growth of the brain depend on one's experience, the challenge is for teachers to vary teaching methods and shift the paradigm from 'one with all' to 'enriched environment' for each student (Caine \& Caine, 1991, 2003; Jesen, 1995; Evan, 2007). The current study investigates the efficacy of various brain-based teaching approach aimed at encouraging students to create various sorts of associations while learning mathematics. In one of the study groups, technology was used as a platform to support these strategies (Al-Balushi \& Al-Balushi, 2018).

\section{GeoGebra Software}

The current learning technique and teaching aid ( $\mathrm{ABM}$ ) must be diverse, and they cannot be limited to the traditional classroom approaches alone. As a result of the constant integration of technology into the educational process, many different types of tools, resources, and teaching methods are introduced into our educational system. Technology can also be used for meaningful learning processes and for understanding a concept clearly (Altiparmak, 2014). Students can interact with educational materials aimed to build required abilities and solve everyday scenarios using their mathematical backgrounds by using computer software. This learning technology needs to be useful and kept in our education system so it will not be in vain. By using new technology in the classroom, evidence shows a relationship amongst ICT-enabled activities, positive attitude towards mathematics, improvement of mathematical learning and students' performance (Kenneth, 1996; Rosas, 2003). According to Jonanssen and Carr (2000), technology is employed as a mindtool to facilitate deep reflective thought and is required for effective learning. Many educators who utilise ICT in their education have 
become aware of the presence of open-source software. An example is GeoGebra Software, which can be used in the process of learning mathematics.

GeoGebra is dynamic mathematics and open-source software that is available for free for the T\&L of mathematics. GeoGebra Software has features in geometric, algebraic, statistics, and calculus. GeoGebra is derived from the words "geometry" and "algebra." GeoGebra develops its application using spreadsheets, graphics, mathematics, and statistics in an easy-to-use package, keeping up with the latest innovations. GeoGebra is also a global leader in teaching and learning (T\&L) for dynamic mathematics and STEM software. GeoGebra, according to Maceková (2013) and Antohe (2009), can be a useful new platform for regular online learning (e-learning). Blossier (2014) also found that students and teachers think highly of the GeoGebra Software. The students have high curiosity and always think to try something new in solving mathematics using GeoGebra Software (Zetriuslita et al., 2020).

\section{Conceptual Learning in Mathematics and Differentiation Topics}

NCTM (2000) defined mathematical conceptual understanding when students are able to: (1) Prove that they can recognise, label and generate examples of concepts; (2) Use and connect models, diagrams, manipulatives and various concepts; (3) Identify and apply principles; (4) Know and apply the definition; (5) Compare and integrate common concepts and principles; (6) Recognise, interpret and apply signs, symbols and variables used to introduce concepts; (7) Making excuses in settings that involve the careful application of the definition of a concept, relationship or representation. The taxonomy levels, (1) Understanding, (2) Remembering and (3) Implementing, can be related to conceptual understanding in mathematics (Anderson et al., 2001).

The importance of conceptual comprehension, along with procedural fluency, has been emphasised as part of students' mathematical competence (Kilpatrick et al., 2001; NCTM, 2000). Berry and Nyman (2003) showed that students can acquire good learning by making connections between procedures and relationships underlying concepts. However, a lack of relationship between these two will result in a lack of conceptual understanding of important concepts in Mathematics (Mahir, 2009). Students can fill these gaps with an understanding of procedures and calculations, which are considered important outcomes with little conceptual understanding (Aspinwall \& Miller, 1997). Students' knowledge of mathematical concepts in schools, such as functions and graphs (Ainsworth, 1999), differentiation (Haciomeroglu et al., 2010), and limits (Szydlik, 2000), has become the subject of an increasing number of studies in mathematics education.

Calculus is considered the basis for advanced Mathematics topics (Additional Mathematics) (Mahir, 2009). Although the topic of differentiation has a major role in calculus, the concept of differentiation is difficult for students (Asiala et al., 1997; Furinghetti \& Paola, 1991). Most students had difficulty with the concept of differentiation in terms of their understanding and comprehension (Bezuidenhout, 2001; Hauger, 2000). Students, for example, may give the correct answer of 'the gradient of the tangent line at a certain point on a curve' as the definition of differentiation, but they 
misinterpret the concept (Amit \& Vinner, 1990; Ubuz, 2001). In addition, students have problems in understanding concepts and linking the rate of change to the concept of differentiation (Bezuidenhout, 1998; Heid, 1988; Orton, 1983).

Another difficulty in understanding the concept is that students also have difficulty in (i) conceptualising the role of limits, (ii) defining algebraic differentiation, (iii) determining the average rate of change and (iv) determining the gradient of a tangent line on a curve at a point (Hankiöniemi, 2006; Orton, 1983). The concept of differentiation should contain an understanding of the fundamental notions that underpin it, such as the rate of change, the gradient of tangent, and limits, as well as the link between them. Although students can accurately answer differentiation problems, they are unable to explain differentiation in terms of rate of change, tangent gradient, and limit (Bingölbali, 2008). Many researchers emphasised the significance of memorisation techniques as the cause of disparities in students' learning and accomplishment in the issue without grasping the underlying notions of the concept of differentiation (Henningsen \& Stein, 1997; Schoenfeld, 1992; Shield, 1998). For most students, differentiation consists of rules and procedures for solving the problem of differentiation, without a clear reason (i.e. instrumental understanding) (Bingölbali, 2008; Thompson, 1994).

Students consider that the concepts and applications of differentiation are abstract and include a variety of formal definitions involving mathematical proof (Tall, 1993). In addition, they struggle with connecting expressions or algebraic equations with graphical representations, tables or others. Hence, students prefer to memorise specific problem-solving steps and follow the procedures. Students do not try to understand the topic of calculus and the concept of differentiation meaningfully and conceptually. Aspinwall and Miller (1997), Mahir (2009) and Tatar and Zengin (2016) stated that one of the reasons why students have difficulty in learning calculus is the lack of conceptual knowledge. In addition, students see calculations performed in solving differentiation problems as a priority, and thus, they focus on procedural knowledge (Aspinwell \& Miller, 1997). The present study focuses on students' conceptual and procedural understanding in learning the application of differentiation. Therefore, an understanding of concepts and procedures should be defined. Arslan (2010) defined conceptual knowledge as requiring students' comprehension of the interpretation of concepts and the relationships between them. Arslan also noted that for conceptual knowledge, understanding the concepts and relationships between them is important. Various teaching methods can be used to help students acquire a balanced conceptual understanding and feel confident in learning the topic of calculus. Given the use of differentiation in calculus, many researchers showed that GeoGebra-assisted instruction has a significant influence on students' conceptual achievement. Mathematics teaching with GeoGebra has a positive impact on students' conceptual achievement in various mathematical disciplines, according to experimental investigations from various grade levels (Dikovic, 2009; Praveen \& Leong, 2013; Tatar, 2012; Tatar \& Zengin, 2016) compared with those who received instructions or interventions based on texts or textbooks. 
In addition, evidence shows that instructions from GeoGebra assistance support students' conceptual knowledge of different courses, including the application of differentiation in calculus. Aydos (2015), for example, looked into the impact of GeoGebra-based mathematics instruction on high school students' conceptual knowledge of limits and differentiation. Aydos discovered that students in the experimental groups who were taught with GeoGebra scored higher on a test measuring conceptual understanding than those who were taught with traditional methods. A comparable study was undertaken by Kepçeolu (2010) for students majoring in Mathematics Education, or trainee teachers. In terms of conceptual understanding, students in the experimental group who got GeoGebra tuition outperformed those who received traditional teaching. Similarly, Tatar and Zengin (2016) discovered that the experimental group whose teaching was conducted using GeoGebra had a better conceptual comprehension of calculus than the control group. Finally, Hutkemri and Zakaria (2014) investigated the impact of GeoGebra on students' achievement relating to their conceptual and procedural knowledge of functions in calculus. When both conceptual and procedural knowledge were considered, students in the experimental group performed significantly higher scores than those in the control group.

\section{Aim}

This study aims to explore the possible effects of the Brain-Based Teaching Approach with the integration of GeoGebra Software on conceptual understanding of the topic of differentiation in rural secondary schools in Malaysia.

\section{METHOD}

\section{Research Design}

This study used a quasi-experimental pre-test-post-test non-equivalent control group design. This design was appropriate for the situation of the study conducted, which was to identify at least one of the characteristics between the groups that would have different expected values even if some experiments had no effect (Cook \& Campbell, 1979). Table 1 shows the quasi-experimental study design used in this study.

Table 1

Quasi-experimental study design table

\begin{tabular}{llll}
\hline Group & Pre-test & Treatment & Post-test \\
\hline Experimental group (B-Geo Module) & $\mathrm{O}_{1}$ & B-Geo Module approach & $\mathrm{O}_{2}$ \\
\hline Control group (P ICT) & $\mathrm{O}_{1}$ & ICT approach & $\mathrm{O}_{2}$ \\
\hline
\end{tabular}

Based on Table 1, in this study, the pre-test that measures the initial ability level of students is represented by $\mathrm{O}_{1}$. The post-test which measures performance after treatment is represented by $\mathrm{O}_{2}$. This experiment was implemented to determine the effectiveness of the intervention given. If the achievement in pre-test $\mathrm{O}_{1}$ did not show the equality between groups for the initial level of ability of the respondent, it would be made as covariate to reconcile the original differences between the groups (Cappelleri \& Trochim, 2015). The sampling method used in this study is purposive sampling. This study involved 118 form 4 students of rural secondary schools who were divided into 
two groups: 60 students in the experimental group and 58 students in the control group. Both groups were from different schools. Table 2 shows the experimental study procedures for both groups as conducted by the researchers.

Table 2

Experimental procedures

\begin{tabular}{ll}
\hline Action & Timeframe \\
\hline Brain-Based Teaching Approach integrated with GeoGebra & One day \\
Software application Workshop and ICT application Workshop & \\
\hline Pre-test & 1 hour \\
\hline Teaching and learning activity & 10 weeks, 70 minutes per week \\
\hline Post-test & 1 hour \\
\hline
\end{tabular}

\section{Research Instruments}

The level of conceptual understanding of the topic of differentiation was measured using the Conceptual Comprehension of the Topic of Differentiation Test (UKKTP) instrument. These conceptual comprehension questions were adapted by the researchers using SPM and previous state-level trial examination questions. These test question items were constructed according to the level of Anderson Taxonomy. The researchers gave the respondents an hour to answer these Conceptual Comprehension test questions. The researchers also developed a rubric for the scoring technique of the Conceptual Comprehension Test. The conceptual understanding rubric was adapted by the researchers using the rubric in Hutkemri's study (2014). To acquire the content validity, the UKKTP instrument and this rubric were reviewed and rated by four Additional Mathematics teachers who had been teaching Additional Mathematics for over 10 years and six Mathematics lecturers who were content experts on the topic of differentiation. Then, a pilot study on 70 Form 4 students was implemented to obtain the instrument reliability. Items tested in pre- and post-tests involved the same form and questions. However, during the post-test, the position of each item was changed to avoid the effects of internal threats in this study. Tables 3 and 4 show the difficulty index and the discrimination index for UKKTP items.

Table 3

Test specification schedule (JSU) according to Anderson Taxonomy level

\begin{tabular}{|c|c|c|c|c|c|c|c|}
\hline \multirow{2}{*}{$\begin{array}{l}\text { Objective of } \\
\text { Study }\end{array}$} & \multirow[t]{2}{*}{ Item no. } & \multirow{2}{*}{$\begin{array}{l}\text { Level according to } \\
\text { Anderson Taxonomy }\end{array}$} & \multicolumn{4}{|c|}{ Subtopic } & \multirow[t]{2}{*}{ Score } \\
\hline & & & 2.1 & 2.2 & 2.3 & 2.4 & \\
\hline \multirow{10}{*}{$\begin{array}{l}\text { Conceptual } \\
\text { understanding }\end{array}$} & Item 1 & Remembering & 1 & & & & 4 \\
\hline & Item 2 & Remembering & & I & & & 4 \\
\hline & Item 3 & Understanding & & & I & I & 4 \\
\hline & Item 4 & Understanding & & I & & I & 4 \\
\hline & Item 5 & Understanding & & 1 & & 1 & 4 \\
\hline & Item 6 & Remembering & I & & & & 4 \\
\hline & Item 7 & Understanding & I & & & & 4 \\
\hline & Item 8 & Implementing & & 1 & & 1 & 4 \\
\hline & Item 9 & Understanding & 1 & & & & 4 \\
\hline & Item 10 & Understanding & & I & I & & 4 \\
\hline Total & 10 & & & & & & 40 \\
\hline
\end{tabular}


Table 4

Difficulty level and difficulty index for UKKTP instruments

\begin{tabular}{llll}
\hline Item no. & Difficulty index & Difficulty level & Follow-up action \\
\hline 1 & 0.51 & Moderate & Accepted \\
\hline 2 & 0.59 & Moderate & Accepted \\
\hline 3 & 0.34 & Moderate & Accepted \\
\hline 4 & 0.72 & Easy & Accepted \\
\hline 5 & 0.69 & Moderate & Accepted \\
\hline 6 & 0.25 & Very hard & Accepted after revision of experts \\
\hline 7 & 0.49 & Moderate & Accepted \\
\hline 9 & 0.44 & Moderate & Accepted \\
\hline 10 & 0.33 & Moderate & Accepted \\
\hline
\end{tabular}

Table 4 shows that item 6 was very difficult. Therefore, this item was improved, and the researchers conducted interviews with the students and the teachers to identify the level of difficulty of this item. Most students responded that they were unable to solve question 6 because they usually answered this question in simple algebraic form. From the interviews with the teachers, this study found that the students were still less proficient in conceptual questions because Form 4 students had not yet adapted themselves to the Additional Mathematics examination. In addition, this item was an adaptation of the SPM examination questions, which had been reviewed by the experts. Therefore, the researchers found that this item could be accepted and included after improvement.

Table 5

Discrimination index for UKKPM instruments

\begin{tabular}{lll}
\hline Item no. & Discrimination index & Items accepted/rejected \\
\hline 1 & 0.88 & Very good \\
\hline 2 & 0.72 & Very good \\
\hline 3 & 0.21 & Marginal needs to be improved \\
\hline 4 & 0.42 & Very good \\
\hline 6 & 0.48 & Very good \\
\hline 7 & 0.34 & Good \\
\hline 8 & 0.21 & Marginal needs to be improved \\
\hline 9 & 0.25 & Marginal needs to be improved \\
\hline 10 & 0.21 & Marginal needs to be improved \\
\hline
\end{tabular}

Based on Table 5, items 3, 7, 8 and 9 had also been improved and reviewed with the experts' help. The experts confirmed that these items could be used because they had been adapted from SPM questions. Therefore, after confirmation from the experts, the researchers decided to keep the items. Overall, the alpha value of the Conceptual Understanding and Problem Solving Test instrument is 0.76 which is above the level of validity acceptable by Pallant (2016). 


\section{Brain-Based Teaching Approach Integrated with GeoGebra Software Module (B- GEO Module)}

The Brain-Based Teaching Approach with integrated GeoGebra Software module was built using the instructional design model, which was the ASSURE model adapted by Abdul (2014). This model is more appropriate because according to Heinich et al. (2002), the ASSURE model is a systematic and simple instructional model to help teachers plan T\&L inside and outside the classroom. The adaption of the ASSURE model, which has three stages and six steps, is the purpose of this research. The design and development phase, the implementation phase, and the module evaluation phase were all included. Analysing learners, declaring objectives, selecting techniques, media, and materials, utilising media and materials, requiring learners' participation, and reviewing and updating were the six phases involved.

The B-Geo Module follows the Assessment and Curriculum Standard Document (DSKP), Secondary School Standard Curriculum (KSSM) for Form 5 Additional Mathematics. The differentiation topic was chosen after the researchers conducted an initial poll to determine the themes to be explored. The content sequence starts from the background, module usage guide, module objectives, Brain-Based Teaching Approach (BBTA) principles, BBTA strategies, teaching sets from 1 to 10 , a summary of T\&L process activities based on BBTA phases, self-training and resources and references. Each set of lessons has four parts, namely, RPH based on brain-based teaching, GeoGebra Applet, Training Sheets and Video Manuals on the Use of GeoGebra Applet. To make it easier for teachers to use this B-Geo Module, the content of each instruction set has been described in the module usage guide. Meanwhile, the researchers followed the learning set 1 to 10 according to the teachers' B-Geo Teaching Module to determine the content of learning materials utilised by students, the B-Geo Module (student). Each learning has a sequence of order with the presence of a GeoGebra applet, examples of questions and answers for solutions, including exercises for students to do during the learning process.

Following the completion of the module prototype, the researchers submitted the B-Geo Module, together with the expert content validation questionnaire, to a variety of expert panels for review and evaluation. This questionnaire has been adapted from questionnaires by Abdul (2015) and Yaakob (2015). The B-Geo Module was evaluated by a total of 13 expert panels. Mathematics experts, module experts, language professionals, Brain-Based Teaching Approach specialists, and GeoGebra specialists are among the experts involved. The panel of experts' opinions, ideas, and criticisms were all used to address the module's flaws and deficiencies. Amongst the aspects that were valued by experts were facial validity (language and punctuation) and content validity (content compatibility with the Malaysian curriculum). The expert panel was given a questionnaire and requested to respond with their thoughts or comments based on the research questions. The questionnaire was related to the aspects: (a) learning outcomes; (b) module design; (c) teaching strategies; (d) T\&L activities; (e) learning materials and (f) assessment. The mean results, percentages, and standard deviations for the expert panel's approval in all six elements are shown in Table 6. 
Table 6

Percentage, mean and standard deviation for experts' agreement

\begin{tabular}{lllll}
\hline No. & Aspect & $\begin{array}{l}\text { Percentage of } \\
\text { experts' agreement }\end{array}$ & $\begin{array}{l}\text { Mean of experts' } \\
\text { approval }\end{array}$ & $\begin{array}{l}\text { Standard } \\
\text { deviation }\end{array}$ \\
\hline 1 & Learning outcome & $93.8 \%$ & 4.69 & 0.42 \\
\hline 2 & Module design & $91.0 \%$ & 4.55 & 0.41 \\
\hline 3 & Teaching strategies & $89.8 \%$ & 4.49 & 0.54 \\
\hline 4 & Teaching and learning activities & $90.0 \%$ & 4.50 & 0.64 \\
\hline 5 & Usability of media and learning materials & $89.6 \%$ & 4.48 & 0.44 \\
\hline 6 & Evaluation & $90.0 \%$ & 4.50 & 0.50 \\
\hline
\end{tabular}

Sidek and Jamaludin (2005) posited that if and only if the content validity percentage is more than $70 \%$, the content validity of the module is good, and vice versa. Referring to Table 6, all percentages of experts' consent exceed 70\%. Therefore, this module was good and could be continued for study.

The next stage was to conduct a pilot study of the module after it had been verified by experts. A pilot study was conducted to determine the extent to which this module could be implemented in the Additional Mathematics T\&L. Another objective was to verify the strengths and weaknesses found in the B-Geo Module. A pilot study of the module was done with 70 Form 4 students and two teachers in two SMK schools in Kedah. This pilot research lasted a week, with each lesson lasting 70 minutes ( 2 hours). These interventions also necessitated infrastructure, such as computer labs and access to the Internet. The researchers worked with Additional Mathematics teachers at a vocational school with a total of 38 students to conduct their intervention. The objective is for the researchers to ensure that the problems that arose during the intervention could be observed directly for immediate action. The study in the next school was conducted by an experienced teacher of Additional Mathematics and involved the use of GeoGebra and the participation of a total of 32 Form 4 students. After conducting a pilot study on the B-Geo Module, the researchers received feedback and ideas on the module. The BGeo Module was improved and refined based on observations, interviews, opinions, comments, and criticisms provided by the teachers and students who participated in this pilot research. After refining the B-Geo Module, this module was ready for use in experimental studies.

\section{Data Analysis Techniques}

The data analysis techniques used are descriptive analysis and inference analysis using the ANCOVA test. The ANCOVA test was used because the Pre-test scores of the Conceptual Differential Topics for the two groups, namely, the experimental group and the control group, were different. Therefore, the Conceptual Comprehension of the Topic of Differentiation Pre-Test (UKKTP) was controlled and turned into covariates in the ANCOVA. The ANCOVA test was conducted using SPSS program version 26 . The test was performed at a significance level of 0.05 to compare the scores of conceptual understandings between the two groups of students. 


\section{FINDINGS}

Descriptive statistical analysis was conducted to identify the mean, minimum and maximum values of the pre-test and post-test questionnaires including the tests for students following the B-Geo Module teaching approach and ICT teaching approach. From another perspective, inferential statistical analysis was performed to obtain significant differences on the dependent variables of the two experimental groups using ANCOVA after the conditions of using ANCOVA were complied with. The results showed that the mean of the conceptual comprehension pre-test score for the B-Geo Module teaching approach is relatively lower than that of the pre-test score for the ICT teaching approach. Moreover, the mean of the conceptual comprehension post-test score for the B-Geo Module teaching approach is relatively higher than that of the post-test score for the ICT teaching approach. Normality results of skewness and kurtosis for conceptual comprehension pre-test and post-test scores based on teaching approaches in the range of -2 to +2 , indicating that the data were normal distribution (Hair et al., 2010). The results of Levene's test findings use the assumption of the uniform mean variance of the conceptual comprehension post-test scores. The significant value for Levene's test is 0.128 , which exceeds the $p>0.05$ value. Therefore, the assumption of variance uniformity has been adhered to. From the homogeneity of regression slope test, no significant relationship exists between teaching approaches and conceptual understanding pre-test $[\mathrm{F}=4.733$, sig $=0.110(\mathrm{p}>0.05)$. Then, from the linearity test for the relationship between the covariate and dependent variables, a significant relationship is found between conceptual understanding pre-test and conceptual understanding post-test $[\mathrm{F}(1,115)=4.726$, sig $=0.032, \mathrm{p}<0.05]$. Therefore, the use of ANCOVA may have been fulfilled. Table 8 shows the summary of the results.

Table 8

One-way ANCOVA test results for test scores of conceptual understandings in differentiation topics.

\begin{tabular}{lllllll}
\hline Source & $\begin{array}{l}\text { Type III sum } \\
\text { of squares }\end{array}$ & Df & $\begin{array}{l}\text { Mean } \\
\text { square }\end{array}$ & F & Sig. & $\begin{array}{l}\text { Partial eta } \\
\text { squared }\end{array}$ \\
\hline Corrected model & $226.059^{\mathrm{a}}$ & 2 & 113.030 & 4.750 & 0.010 & 0.08 \\
\hline Intercept & 1875.222 & 1 & 1875.222 & 78.812 & 0.000 & 0.41 \\
\hline $\begin{array}{l}\text { Conceptual understanding } \\
\text { pre-test }\end{array}$ & 112.459 & 1 & 112.459 & 4.726 & 0.032 & 0.04 \\
\hline Teaching approach & 158.061 & 1 & 158.061 & 6.643 & 0.011 & 0.06 \\
\hline Error & 2736.280 & 115 & 23.794 & & & \\
\hline Total & 29934.000 & 118 & & & & \\
\hline Corrected total & 2962.339 & 117 & & & & \\
\hline
\end{tabular}

a. R Squared $=0.076$ (adjusted $R$ squared $=0.060$ )

The result of the one-way ANCOVA test shows a significant difference in mean conceptual understanding post-test $[\mathrm{F}(1,115)=6.643$, $\mathrm{Sig}=0.011, \mathrm{p}<0.05]$ between teaching approaches whilst adjusting for the conceptual understanding pre-test. The partial eta squared value indicates that the teaching approach effect size is small (0.06) (Cohen, 1988). This value described by the variance of conceptual understanding posttest is explained by the teaching approaches $(6 \%)$. Ideally, this number would be moderate. 
Table 9

Marginal average estimated results of the conceptual understanding post-test score for teaching approach using the B-Geo and P ICT Modules

\begin{tabular}{lccc}
\hline & & \multicolumn{2}{c}{$95 \%$ confidence interval } \\
\hline Teaching approach & Average & Lower limit & Upper limit \\
\hline B-Geo Module teaching approach (B-Geo Module) & $16.28^{\mathrm{a}}$ & 15.02 & 17.54 \\
\hline ICT teaching approach (PICT) & $13.92^{\mathrm{a}}$ & 12.64 & 15.20 \\
\hline
\end{tabular}

The estimated marginal average of the conceptual comprehension post-test scores was calculated to control the effects of the covariate. The results showed that the average comprehension post-test score of the topic differentiation for students following the BGeo Module teaching approach was 16.28. Meanwhile, the average score for concept comprehension post-test of the topic of differentiation for students who follow the ICT teaching approach was 13.92. These findings indicated that the average test score of conceptual comprehension of the topic differentiation for students using the B-Geo Module teaching approach was higher than the average test score of conceptual comprehension of the topic for students following the ICT teaching approach.

\section{DISCUSSION}

The result of the ANCOVA test shows a significant relationship between pre-test and post-test conceptual understanding. This result shows an impression of the conceptual understanding pre-test against the conceptual understanding pre-test. When viewed in terms of changes in the value of the min conceptual understanding, this relationship is positive. That is, as the conceptual understanding of the pre-test amongst students increases, the conceptual understanding of the post-test also increases. The results of this study also show significant differences in conceptual understanding between groups of students who are studying using ICT BBL (B-Geo) and those using ICT approaches. The result of the study shows that groups that use ICT BBL (B-Geo) have a better conceptual understanding. The Brain-Based Teaching Approach with the integration of GeoGebra affects students' conceptual understanding of the topic of differentiation. This means that this approach and GeoGebra Software help students understand the conceptual understanding of the topic of differentiation. Unlike conventional schooling methods, which are often said to hinder learning and neglect the brain's natural learning process, the Brain-Based Teaching Approach is believed to enhance learning, specifically in understanding the concept of a topic because of its holistic approach to students. This learning approach conforms to the best operating principles of the natural processes of the brain, aiming to achieve attention, understanding, meaning and memory (Jensen, 1996). Learning that is 'authentic,' in the sense that it is related to real-world challenges and applications, can help students learn more effectively (Caine \& Caine, 1991, 2003; Sousa, 1995, 1998; Jensen, 1998).

The results of the study using the ANCOVA test also showed significant differences in conceptual understanding between groups of students using ICT BBL (B-Geo) and traditional approaches through the pre-test as a covariate. This result shows that the increase in conceptual understanding between groups of students using ICT BBL (BGeo) and traditional approaches also has a significant difference caused by the impression given by the pre-test conceptual understanding exam. The differences in 
students' conceptual understanding in the early stages before the experimental study was carried out also became a determinant of the success of the approach used in the study conducted. However, using ICT BBL (B-Geo) gives a better impression through the intermediate pre-test as a covariate. The factors that may influence are student experience and IQ. As the development and growth of the brain depend on someone's experience, the real challenge is for teachers to vary teaching methods and shift their paradigm from 'one for all' to 'enriched environment' for every student (Caine \& Caine, 1991, 2003; Jensen, 1998; Evans, 2007). In the context of this study, the role of the teacher is to provide an appropriate classroom climate, which emphasises instructions that accommodate how the brain learns, which will improve brain function in processing and constructing data correctly, according to the level of each student. In addition, the GeoGebra Software also plays an important role because it enhances students' learning specifically in conceptual understanding. The findings of the researchers can prove that students' conceptual understanding of the topic of differentiation can be improved by using a different approach from the conventional approach commonly used by teachers. In addition, the results of this study also show that using GeoGebra Software is one of the factors for students to improve their conceptual understanding of the topic of differentiation.

Students' conceptual understanding of the topic of differentiation can be seen when students use the graph animations, videos and exercises found in this B-Geo Module. In experimental studies from different grade levels, Mathematics teaching with GeoGebra has a positive influence on students' conceptual achievement in different mathematical topics (Dikovic, 2009; Shadaan \& Eu, 2013; Tatar, 2012; Zengin \& Tatar, 2015) compared with those who received instructions or interventions based on texts or textbooks. Evidence also shows that the GeoGebra instructional aid can support students' conceptual understanding for different courses, including the application of differentiation in calculus, such as those stated by Aydos (2015), Kepçeoğlu (2010), Tatar and Zengin (2016) and Hutkemri and Zakaria (2014). The results of the combination of the two teaching approaches help further the students' understanding of the topic of differentiation, which refers to the strategies used in the B-Geo Module. The B-Geo Module helps teachers to organise students' learning environment with the help of PPBO strategy with the integration of GeoGebra Software to optimise brain function and further help students' conceptual understanding of differentiation from the beginning all the way to problem-solving questions.

The results of this study show the effect of the Brain-Based Teaching Approach integrated with GeoGebra on students' increased conceptual understanding, which in turn can help improve the achievement of rural secondary school students. Therefore, the percentage gap between urban and rural secondary schools can be reduced. Indirectly, this study can contribute to the passing percentage of the SPM Examination in the subject of Additional Mathematics.

\section{CONCLUSION}

From the results, the Brain-Based Teaching Approach with GeoGebra integration has effectively improved students' conceptual understanding of the topic of differentiation. 
By using the B-Geo Module, students can see abstractly the use of differentiation in daily life through the help of GeoGebra Software. Indirectly, the activities in the module can stimulate students' minds to learn differentiation topics and also their interest in using technology in mathematics learning to provide a better impression of understanding conceptual differentiation. Students can improve their conceptual understanding when they are actively involved in activities implemented using the BGeo Module. The researchers would like to suggest interested parties to conduct a study on the Brain-Based Teaching Approach with GeoGebra integration using different topics in addition to the topics used by researchers, that is, differentiation. In addition, in terms of improving the methodology of the study, the researchers suggest that those interested in conducting a quasi-experimental study similar to the present study should have very systematic and organised time management so that the study runs smoothly. Future researchers should also consider the time allotted whilst conducting experimental studies.

\section{ACKNOWLEDGEMENT}

This research was funded by Fundamental Research Grant Scheme Universiti Sains Malaysia, Grant No. 203/PJJAUH/6711688

\section{REFERENCES}

Abdul, R. N. M. (2015). Pembinaan Modul Berasaskan Pendekatan Projek Untuk Meningkatkan Kemahiran Berkomunikasi Murid Tadika, 16(2). https://doi.org/10.1377/hlthaff.2013.0625

Abidin, Z. (2012). Pendidikan Matematika Fakultas. Zainal Abidin Journal, XIII(1), 183-196.

Altıparmak, K. (2014). Impact of Computer Animations in Cognitive Learning: Differentiation. International Journal of Mathematical Education in Science and Technology, 45(8), 1146-1166. https://doi.org/10.1080/0020739X.2014.914256

Al-Balushi, K. A., \& Al-Balushi, S. M. (2018). Effectiveness of brain-based learning for grade eight students' direct and postponed retention in science. International Journal of Instruction, 11(3), 525-538. https://doi.org/10.12973/iji.2018.11336a

Abu, N. E., \& Leong, K. E. (2014). Hubungan Antara Sikap, Minat, Pengajaran Guru dan Pengaruh Rakan Sebaya Terhadap Pencapaian Matematik Tambahan Tingkatan 4, $1-10$.

Amit, M., \& Vinner, S. (1990). Some misconceptions in calculus: Anecdotes or the tip of an iceberg? ,. Proceedings of the 14th International Conference of the International Group for the Psychology of Mathematics Educations, 3-10.

Anderson, L. W., Krathwohl, D. R., Airasian, P. W., Cruikshank, K. A., Mayer, R. E., Pintrich, P. R., Raths, J., \& Wittrock, M. C. (2001). Taxonomy for Assessing a Revision oF Bloom's Taxonomy $0 F$ Educational Objectives. Longman Publishers. https://www.uky.edu/ rsand1/china2018/texts/Anderson-Krathwohl 
Antohe, V. (2009). Limits of Educational Soft "GeoGebra" in a Critical Constructive Review, VII, 47-54.

Arshad, M. N., \& Abdullah, A. H. (2014). Menjana Kemahiran Berfikir Aras Tinggi (KBAT) Dalam Penyelesaian Masalah Matematik Tambahan. Konvensyen Antarabangsa Jiwa Pendidik 2014, 1981.

Arslan, S. (2010). Traditional instruction of differential equations and conceptual learning. Teaching Mathematics and Its Applications, 29(2), 94-107. https://doi.org/10.1093/teamat/hrq001

Asiala, M., Cottrill, J., Dubinsky, E., \& Schwingendorf, K. E. (1997). The development of students' graphical understanding of the derivative. Journal of Mathematical Behavior, 16(4), 399-431. https://doi.org/10.1016/s0732-3123(97)90015-8

Aydos, M. (2015). The impact of teaching mathematics with Geogebra on the conceptual understanding of limits and continuity: The case of Turkish gifted and talented students. İhsan Doğramac1 Bilkent University.

Ayu Erlina (2013). Kesan Penggunaan Perisian Geogebra Ke Atas Keupayaan Penyelesaian Masalah Dan Pencapaian Matematik Pelajar. Masters Thesis. Selangor: Universiti Kebangsaan Malaysia.

Bezuidenhout, J. (1998). First-year university students' understanding of rate of change. International Journal of Mathematical Education in Science and Technology, 29(3), 389-399. https://doi.org/10.1080/0020739980290309

Bezuidenhout, J. (2001). Limits and continuity: Some conceptions of first-year students. International Journal of Mathematical Education in Science and Technology, 32(4), 487-500. https://doi.org/10.1080/00207390010022590

Bingölbali, E. (2008). Learning about the concept of derivative suggestions for difficulties and conceptual understanding. Pegem Academy, Ankara.

Blossier, M. (2014). GeoGebra:The graphing calculator for functions, geometry, algebra, calculus, statistics and 3D math! Dynamic Mathematics for Learning and Teaching. www.geogebra.org

Caine, R. N. (Ed. . (2009). 12 Brain/mind learning principles in action: Developing executive functions of the human brain. Corwin Press.

Caine, R. N., \& Caine, G. (1991). Teaching and The Human Brain. : (Issue Issue 218). Association for Supervision and Curriculum Development.

Caine, R.N., \& Caine, G. (2003). 12 Brain / mind learning principles in action. The fieldbook for making connections, teaching and the human brain. Corwin Press.

Caine, Renate Nummela, Caine, G., McClintic, C., \& Klimek, K. (2005). 12 brain/mind learning principles in action: The fieldbook for making connections, teaching, and the human brain. Corwin Press. 
Cappelleri, J. C., \& Trochim, W. M. (2015). Regression Discontinuity Design. In International Encyclopedia of the Social \& Behavioral Sciences: Second Edition (Second Edi, Vol. 19, Issue 2008). Elsevier. https://doi.org/10.1016/B978-0-08-0970868.44049-3.

Cohen, J. (1988). Statistical Power Analysis for the Behavioral Sciences. New York, NY: Routledge Academic.

Cook , T. D. , \& Campbell, D. T. (1979). Quasi-experimentation: Design and analysis for field settings. Houghton Mifflin.

Cuban, L., Kirkpatrick, H., \& Peck, C. (2001). High access and low use of technologies in high school classrooms: Explaining an apparent paradox. American Educational Research Journal, 38(4), 813-834. https://doi.org/10.3102/00028312038004813

Dikovic, L. (2009). Implementing dynamic mathematics resources with geogebra at the college level. International Journal of Emerging Technologies in Learning. https://doi.org/10.3991/ijet.v4i3.784

Evans, G. (2007). Counselling Skills for Dummies. John Wiley and Sons.

Fazil, F., \& Salmiza, S. (2016). Kesan Pendekatan Pengajaran Berasaskan Otak Terhadap Motivasi Pembelajaran Sains. Jurnal Pendidikan Sains \& Matematik Malaysia, 6(1), 68-78.

Furinghetti, F., \& Paola, D. (1991). The construction of a didactic itinerary of calculus starting from students' concept images (ages 16-19). International Journal of Mathematical Education in Science and Technology, 22(5), 719-729. https://doi.org/10.1080/0020739910220503.

Hair, J. F., Black, W. C., Babin, B. J., \& Anderson, R. E. (2010). Multivariate Data Analysis: A Global Perspective: Pearson Education International. New Jersey.

Hankiöniemi, M. (2006). Is there a limit in the derivative? Exploring students' understanding of the limit of the difference quotient. In M. B. (Ed.) (Ed.), Proceedings of the fourth congress of the European society for research in mathematics education. European Research in Mathematics Education.

Hauger, G. S. (2000). Instantaneous rate of change: A numerical approach. International Journal of Mathematical Education of Science and Technology, 31(6), 891-897.

Heid, K. M. (1988). Resequencing skills and concepts in applied calculus using the computer as a tool. Journal for Research in Mathematics Education, 19(1), 3-25.

Heinich, R., Molenda, M., Russell, J. D., \& Smaldino, S. E. (2002). Instructional media and technologies for learning (7th ed.). Merrill Prentice Hall.

Henningsen, M., \& Stein, M. K. (1997). Mathematical tasks and student cognition: Classroom-based factors that support and inhibit high-level mathematical thinking and reasoning. Journal for Research in Mathematics Education, 28(5), 524. 
Hutkemri, Z. (2013). Penggunaan dan keberkesanan modul pengajaran geogebra ke atas pengetahuan konseptual dan prosedural matematik fungsi dan had fungsi. Tesis PhD. Selangor: Universiti Kebangsaan Malaysia.

Hutkemri, \& Zakaria, E. (2014). Impact of using GeoGebra on students' conceptual and procedural knowledge of limit function. Mediterranean Journal of Social Sciences, 5(23), 873-881. https://doi.org/10.5901/mjss.2014.v5n23p873

Jesen, E. (1995). Brain - Based Learning. The Brain Store Publishing.

Jonanssen, \& Carr. (2000). "Mindtools: Affording Multiple Knowledge Representations for Learnings" in S.P. Lajoie [ed]. Lawlence Erlbaum Associates, Hillsdale, NJ, 165196.

Jumiran, M. N. (2014). Kesan Teknik "HunTTO Square" Terhadap Pencapaian Pelajar Bagi Mata Pelajaran Matematik Di Sekolah Rendah. Masters thesis. Johor: Universiti Tun Hussein Onn Malaysia.

Kailani, I., \& Ismail, R. @ N. (2010). Diagnosis Penguasaan Dan Kesalahan Lazim Dalam Tajuk Pembezaan Di Kalangan Pelajar Sekolah Menengah Di Daerah Johor Bahru (Vol. 21, Issue 1). Universiti Teknologi Malaysia.

Kartikaningtyas, V., Kusmayadi, T. A., \& Riyadi, R. (2017). Brain based learning with contextual approach to mathematics achievement. International Journal of Science and Applied Science: $\quad$ Conference $\quad$ Series, $2(1), \quad 421$. https://doi.org/10.20961/ijsascs.v2i1.16760

Kementerian Pendidikan Malaysia. (2015). Buletin anjakan. Buletin transformasi pendidikan Malaysia. Pelan Pembangunan Pendidikan Malaysia 2013-2025, Bil 4/2015. Kementerian Pendidikan Malaysia.

Kenneth. (1996). "Calculators in the Mathematics Curriculum: The Scope of Personal Computational Technology." In A. J. B. et al. [eds] (Ed.), International Handbook of Mathematics Education, Part 1 (pp. 435-468). Kluwer Academic Publishers.

Kepçeoğlu, İ. (2010). The effect of using geogebra in teaching limit and continuity on pre-service teachers' academic achievement and conceptual learning. Marmara University, İstanbul, Turkey.

Khor, M. K., \& Ruzlan, M. A. (2016). Penggunaan Geogebra Dalam Pembelajaran Matematik Melalui Pembelajaran Modular. International Seminar on Generating Knowledge Through Research, 1(October), 147-154.

Maceková, M. A. (2013). Case study: teaching reflection at secondary vocational school using interactive whiteboard and GeoGebra. 1, 98-106.

Mahir, N. (2009). Conceptual and procedural performance of undergraduate students in integration. International Journal of Mathematical Education in Science and Technology, 40(2), 201-211. https://doi.org/10.1080/00207390802213591

Nasir, N. M., Hashim, Y., Zabidi, S. F. H. A., Awang, R. J., \& Zaihidee, E. M. (2013). 
Preliminary study of student performance on algebraic concepts and differentiation. World Applied Sciences Journal, 21(SPECIAL ISSUE3), 162-167. https://doi.org/10.5829/idosi.wasj.2013.21.am.21140

NCTM (National Council of Teachers of Mathematics). (2000). Principles and Standards for School Mathematics. VA: NCTM, Inc.

Nordin, N., Zakaria, E., Mohamed, N. R. N., \& Embi, M. A. (2010). Pedagogical usability of the geometer's sketchpad (GSP) digital module in the mathematics teaching. Turkish Online Journal of Educational Technology.

Nurjanah, Dahlan, J. A., \& Wibisono, Y. (2020). The Effect of Hands-On and Computer-Based Learning Activities on Conceptual Understanding and Mathematical Reasoning. International Journal of Instruction, 14(1), 143-160. https://doi.org/10.29333/IJI.2021.1419A

Orton, A. (1983). Students' understanding of differentiation. Educational Studies in Mathematics, 14(3), 235-250. https://doi.org/10.1007/BF00410540

Pallant, J. (2016). SPSS Survival Manual: A step by step guide to data analysis using IBM SPSS (sixth edit). Allen \& Unwin.

Park, J. (2013). Is the derivative a function? If so, how do students talk about it? International Journal of Mathematical Education in Science and Technology, 44(5), $624-640$.

Praveen, S., \& Leong, K. E. (2013). Effectiveness of Using Geogebra on Students ' Understanding in Learning Circles. The Malaysian Online Journal of Educational Technology, 1(4), 1-11.

Purwadi, I. M. A., Sudiarta, I. G. P., \& Suparta, I. N. (2019). The effect of concretepictorial-abstract strategy toward students' mathematical conceptual understanding and mathematical representation on fractions. International Journal of Instruction, 12(1), 1113-1126. https://doi.org/10.29333/iji.2019.12171a

Puteh, M., \& Khalin, S. Z. (2016). Mathematics Anxiety and Its Relationship with the Achievement of Secondary Students in Malaysia. International Journal of Social Science and Humanity, 6(2), 119-122. https://doi.org/10.7763/ijssh.2016.v6.630

Rosas, R. et al. (2003). "Beyond Nintendo: Design and Assessment of Educational Video Games for First and Second Grade Students." Computers \& Education, 40(1), 71-94.

Saad, N. S. (2002). Teori dan Perkaedahan Pendidikan Matematik. Prentice Hall Inc.

Schoenfeld, A. H. (1992). Learning to think mathematically: Problem solving, metacognition, and sense making in mathematics. In D. A. Grouws (Ed.), Handbook of research on mathematics teaching and learning.

Shield, M. (1998). Mathematics textbooks: messages to students and teachers. Teaching mathematics in new times. In \& E. W. (Eds. . C. Kanes, M. Goos (Ed.), Proceedings of 
the 21st Annual Conference of the Mathematics Education Research Group of Australia. Merga.

Sidek, M. N., \& Jamaludin, A. (2005). Pembinaan Modul: Bagaimana Membina Modul Latihan dan Modul Akademik. Penerbit Universiti Putra Malaysia.

Sousa, D. A. (1995). How the brain learns: A classroom teacher's guide. In National Association of Secondary School Principals.

Tall, D. (1993). Students' Difficulties in Calculus. Proceedings of Working Group 3 on Students' Difficulties in Calculus, ICME-7, Proceedings of Working Group 3 on Students' Difficulties in Calculus, ICME-7, 13-28. https://doi.org/Canada

Tatar, E. (2012). The effect of dynamic mathematics software on achievement in mathematics: The case of trigonometry. Energy Education Science and Technology Part B: Social and Educational Studies. https://doi.org/10.1016/j.sbspro.2011.12.038

Tatar, E., \& Zengin, Y. (2016). Conceptual Understanding of Definite Integral with GeoGebra. Computers in the Schools, 33(2). https://doi.org/10.1080/07380569.2016.1177480

Thompson, P. (1994). Images of rate and operational understanding of the fundamental theorem of calculus. Educational Studies in Mathematics, 229-274.

Ubuz, B. (2001). First year engineering students' learning of point of tangency, numerical calculation of gradients, and the approximate value of a function at a point through computers. Journal of Computers in Mathematics and Science Teaching, 20(1), 113-137.

Yaakob, M. N. (2015). Reka Bentuk Model Kurikulum M-Pembelajaran Pengajian Profesional Di Institut Pendidikan Guru.

Yahya, S. Z., \& Amir, R. (2018). Kebimbangan Matematik Dan Pencapaian Matematik $\begin{array}{lllll}\text { Tambahan. Journal of Nusantara Studies (JONUS), } & 3(2),\end{array}$ https://doi.org/10.24200/jonus.vol3iss2pp124-133

Zandieh, M. (2000). A theoretical framework for analyzing students' understanding of the concept of derivative. CBMS Issues in Mathematics Education, 8, 103-127.

Zengin, Y. (2018). Examination of the constructed dynamic bridge between the concepts of differential and derivative with the integration of GeoGebra and the ACODESA method. Educational Studies in Mathematics, 99(3), 311-333. https://doi.org/10.1007/s10649-018-9832-5

Zetriuslita, Nofriyandi, \& Istikomah, E. (2020). The Increasing Self-Efficacy and SelfRegulated through GeoGebra Based Teaching reviewed from Initial Mathematical Ability (IMA) Level. International Journal of Instruction, 14(1), 587-598. https://doi.org/10.29333/IJI.2021.14135A 